prof. dr hab. inz.. Marek Bartosik

dr inz. Ryszard Lasota

dr inz. Franciszek Wójcik

Politechnika Łódzka

\title{
Wyłączanie prądów wstecznych przez ultraszybkie wyłączniki próżniowe
}

\begin{abstract}
W artykule przeanalizowano wymagania dotyczace ultraszybkich wytaczników próżniowych pradu statego klasy $V$, wykorzystujacych metode impulsu przeciwpradu IPP. Opisano wyłaczanie metoda IPP silnych pradów statych zgodnych oraz wstecznych (występujacych $m$. in. podczas rekuperacji energii), zarówno $w$ obwodach o przewadze indukcyjności jak $i$ rezystancji. Wykazano przydatność metody IPP $w$ dowolnych warunkach łaczeniowych $w$ trakcji kolejowej.
\end{abstract}

\section{Wprowadzenie.}

Obecny poziom rozwoju techniki łączenia silnych prądów stałych umożliwia konstruowanie klasycznych wyłączniki magnetowydmuchowych WM relatywnie słabo ograniczających prądy zwarciowe.

Po wejściu Polski do UE pojawiła się konieczność stosowania norm unijnych opisujących wymagania i klasyfikujących aparaturę łączeniowa, stanowiących podstawę do opracowywania dokumentacji techniczno-ruchowej, warunków technicznego odbioru produkowanej aparatury łaczeniowej oraz wykonywania badań. Dwie podstawowe normy krajowe $[2,3]$ dotyczące trakcyjnych wyłączników prądu stałego zostały zastapione ponad dziesięcioma normami EN odwołującymi się do wielu innych norm szczegółowych. Przykładowo norma [4], wprowadza trzy typy charakterystyk wyłączeniowych, dzieląc wyłączniki na: wyłączniki quasi-szybkie (S), wyłączniki szybkie ograniczające prąd $(\mathbf{H})$, wyłączniki bardzo szybkie ograniczające prąd (V).

Wyłączniki takie powinny odznaczać się własnościami pokazanymi $\mathrm{w}$ tabeli 1 .

Większość znanych WM można zaliczyć do wyłączników quasi - szybkich klasy $\mathbf{S}$, zapewniających przerwanie prądu, ale ograniczenie spodziewanego prądu może nie występować. Tylko część WM można zaliczyć do wyłączników szybkich klasy $\mathbf{H}$, przy czym ograniczają one prąd z co najwyżej umiarkowaną skutecznością, tj. współczynniki ograniczania prądu $\mathrm{C}_{\mathrm{o}}=\mathrm{I}_{\mathrm{o}} / \mathrm{I}_{\mathrm{Nss}}$ są zazwyczaj większe od 0,5 $\left(\mathrm{I}_{\mathrm{o}}\right.$ - prąd ograniczony). W praktyce żaden $\mathrm{z}$ WM spotykanych

w systemach trakcji kolejowej zasilanej napięciem 3 $\mathrm{kV}$ nie spełnia wymagań klasy $\mathrm{V}$.

Osiagnnięcie znacznie skuteczniejszego ograniczania zwarciowych prądów stałych stało się możliwe dzięki zastosowaniu w wyłącznikach trakcyjnych nowych zasad działania, wykorzystujących metody komutacji naturalnej KN lub wymuszonej KW.

- Komutacja naturalna KN jest definiowana jako metoda sprowadzania prądu stałego do zera bez dostarczania energii elektrycznej ze źródla zewnętrznego, za pomocą układu wyłączającego wykorzystującego zespół naturalnych właściwości poszczególnych podzespołów tego układu i zjawisk w nim występujących podczas wyłączania prądu roboczego, przeciążeniowego lub zwarciowego.

- Komutacja wymuszona KW jest definiowana jako metoda sprowadzania prądu stałego do zera wskutek dostarczania ze źródła zewnętrznego energii elektrycznej, za pomocą układu wyłączającego wykorzystującego zasadę superpozycji wytworzonego impulsu prądowego oraz wyłączanego prądu roboczego, przeciążeniowego lub zwarciowego.

Spośród kilkunastu sklasyfikowanych możliwości realizacji technicznej obu metod [1], w systemach trakcji kolejowej zasilanej napięciem stałym $3 \mathrm{kV}$ znalazła zastosowanie metoda $\mathbf{K W}$, w postaci ultraszybkiego wyłączania silnych prądów stałych w próżni

Tabela 1. Przykładowe wymagania dla wyłączników podstacyjnych [4].

\begin{tabular}{|c|c|c|c|c|}
\hline $\begin{array}{c}\text { Klasa } \\
\text { wyłącznika }\end{array}$ & $\begin{array}{c}\text { Czas } \\
\text { otwierania } \\
{[\mathrm{ms}]}\end{array}$ & $\begin{array}{c}\text { Całkowity czas } \\
\text { wyłączania }[\mathrm{ms}]\end{array}$ & $\begin{array}{c}\text { Stosunek } \mathrm{I}_{\text {Nss }} \text { do } \mathrm{i}_{\mathrm{t}} \\
{[-]}\end{array}$ & $\begin{array}{c}\text { di/dt przy } \mathrm{t}=0 \\
{[\mathrm{kA} / \mathrm{ms}]}\end{array}$ \\
\hline $\mathrm{S}$ & $\leq 15$ & $\leq 30$ & $\geq 3,5$ & $\geq 1,7$ \\
\hline $\mathrm{H}$ & $\leq 5$ & $\leq 20$ & $\geq 7$ & $\geq 5$ \\
\hline $\mathrm{V}$ & $\leq 1$ & $\leq 4$ & dowolny & dowolny \\
\hline $\begin{array}{l}\mathrm{I}_{\text {Nss }}-\text { prąd znamionowy zwarciowy, } \mathrm{i}_{\mathrm{t}}-\text { prąd nastawczy wyłącznika, di/dt }- \text { stromość } \\
\text { wzrostu } \mathrm{I}_{\text {Nss }}\end{array}$
\end{tabular}


za pomocą impulsu przeciwprądu, zwanego dalej zasadą IPP.

Przydatne w praktyce w systemach trakcyjnych DC $3 \mathrm{kV}$ są trzy warianty budowy układu wyłączającego UW wykorzystującego zasadę IPP, zależne od rodzaju elementów: głównego, wyłączającego prąd główny oraz pomocniczego, załączającego przeciwprąd:

- UW próżniowy (UWV) (dwie komory próżniowe, główna i pomocnicza),

- UW tyrystorowy (dwa tyrystory lub zespoły tyrystorów, główny i pomocniczy),

- UW hybrydowy (komora próżniowa główna i pomocniczy tyrystor lub zespół tyrystorów).

Najbardziej racjonalny z technicznego i ekonomicznego punktu widzenia jest UW próżniowy. Działające na zasadzie IPP ultraszybkie wyłączniki próżniowe prądu stałego typu DC zostały zaakceptowane na podstawie krajowych norm do stosowania w systemie trakcji kolejowej $3 \mathrm{kV}$ i od ponad 10 lat sa użytkowane w elektrycznych zespołach trakcyjnych, nadto w lokomotywach, a stosowne certyfikaty posiadają już także próżniowe podstacyjne. Wyłączniki DC w pełni odpowiadają wymaganiom klasy $\mathbf{V}$, działając ultraszybko i bardzo skutecznie ograniczając prądy zwarciowe, w sposób nieosiągalny dla WM. Ogromne walory użytkowe wyłączników DC wynikają z ich parametrów eksploatacyjnych oznaczonych zaciemnionymi polami $\mathrm{w}$ tabeli 2 .
Metoda IPP ma charakter uniwersalny i nie ma teoretycznych ograniczeń jej zastosowania przy dowolnej wartości napięcia i prądu. Dotychczasowe ograniczenia praktyczne w jej stosowaniu wynikały $\mathrm{z}$ niewystarczających właściwości elementów układu wyłączającego w stosunku do wymagań technicznych. Dopiero w układach tyrystorowych została ona zastosowana na szeroką skalę. Pomimo wielu cennych zalet, z których najważniejsze to szybkość działania, bardzo mały współczynnik ograniczania prądu zwarciowego, stosunkowo niewielkie energie przepięć łączeniowych, wyłączniki tyrystorowe nie znalazły szerszego zastosowania w obwodach wysokiego napięcia, głównie ze względu na konieczność stosowania wymuszonego odprowadzania ciepła wydzielającego się pod wpływem dużych strat mocy w stanie przewodzenia. Pojawienie się na rynku nowoczesnych komór próżniowych o gwarantowanych przez wiele lat wysokich parametrach technicznych oraz wysokoenergetycznych ograniczników przepięć, otworzyło nowe możliwości wykorzystania tej metody do budowy nowej generacji próżniowych wyłączników prądu stałego.

Metoda IPP w przypadku wyżej opisanych UW tyrystorowych oraz hybrydowych pozwala na budowę wyłączników spolaryzowanych, zdolnych do wyłączania prądu przepływającego tylko w założonym kierunku, zwanego dalej prądem zgodnym. Wyłączanie prądu o kierunku przeciwnym, zwanego dalej

Tabela 2. Zestawienie wybranych parametrów ultraszybkich wyłączników typu DC dla kolei

\begin{tabular}{|c|c|c|c|}
\hline L. p. & \multicolumn{2}{|c|}{ Parametry, jednostki } & Wartości parametrów \\
\hline 1 & N. z. izolacji & $\mathrm{U}_{\mathrm{Nm}} \quad[\mathrm{V}]$ & 3000 \\
\hline 2 & N. z. łączeniowe $\quad \mathrm{U}_{\mathrm{Ne}}$ & {$[\mathrm{V}]$} & 3000 \\
\hline 3 & P. z. ciaggły & $\mathrm{I}_{\mathrm{Ne}} \quad[\mathrm{A}]$ & $400,630,800,1600,2500,3150$ \\
\hline 4 & P. z. wyłączalny / przy s. c. & $\mathrm{I}_{\mathrm{Nss}} / \tau_{\mathrm{c}} \quad[\mathrm{kA} / \mathrm{ms}]$ & $50 / 10,80 / 20,120 / 30$ \\
\hline 5 & Początkowa stromość $\quad \mathrm{I}_{\mathrm{Nss}}$ & $\mathrm{s}_{\mathrm{i}} \quad[\mathrm{A} / \mu \mathrm{s}]$ & $\leq 7$ \\
\hline 6 & P. ograniczony / przy s. c. $i_{0} / \tau_{c}{ }^{1)}$ & {$[\mathrm{kA} / \mathrm{ms}]$} & $\left(\mathrm{i}_{\mathrm{t}}+7,5\right) / 10 ;\left(\mathrm{i}_{\mathrm{t}}+3,75\right) / 20 ;\left(\mathrm{i}_{\mathrm{t}}+2,5\right) / 30$ \\
\hline 7 & W. o. p. $\mathrm{C}_{\mathrm{o}}=\mathrm{i}_{\mathrm{o}} / \mathrm{I}_{\mathrm{Nss}} /$ przy s.c. & $\mathrm{C}_{\mathrm{o}} / \tau_{\mathrm{c}}^{2)}[-/ \mathrm{ms}]$ & $0,2 / 10 ; 0,125 / 20 ; 0,1 / 30^{6)}$ \\
\hline 8 & Całka Joule'a / przy s. c. $I^{2} t / \tau_{c}{ }^{2)}$ & {$\left[\mathrm{A}^{2} \mathrm{~s} / \mathrm{ms}\right]$} & $\leq 120 \times 10^{3} / 10 ; \leq 50 \times 10^{3} / 20 ; \leq 40 \times 10^{3} / 30$ \\
\hline 9 & Przepięcie łączeniowe $\quad \mathrm{u}_{\mathrm{m}}$ & {$[\mathrm{kV}]$} & $\leq 10$ \\
\hline 10 & C. własny otwierania & {$[\mathrm{ms}]$} & 0,6 \\
\hline 11 & C. wyłączania / przy s. c. $\mathrm{t}_{\mathrm{w}} / \tau_{\mathrm{c}}{ }^{2)}$ & {$[\mathrm{ms} / \mathrm{ms}]$} & $\leq 2,5 / 10 ; \leq 4 / 20 ; \leq 5 / 10$ \\
\hline 12 & P. nastawczy & {$[\mathrm{A}]$} & $400 \div 4000$ \\
\hline 13 & Trwałość łączeniowa & [ł] (łączeń) & $10000(2 \times 5000)^{4)}$ \\
\hline 14 & Trwałość mechaniczna $\quad \mathrm{n}_{\mathrm{m}}{ }^{4)}$ & [cp] (cykli) & $20000(2 \times 10000)^{4)}$ \\
\hline \multicolumn{4}{|c|}{ 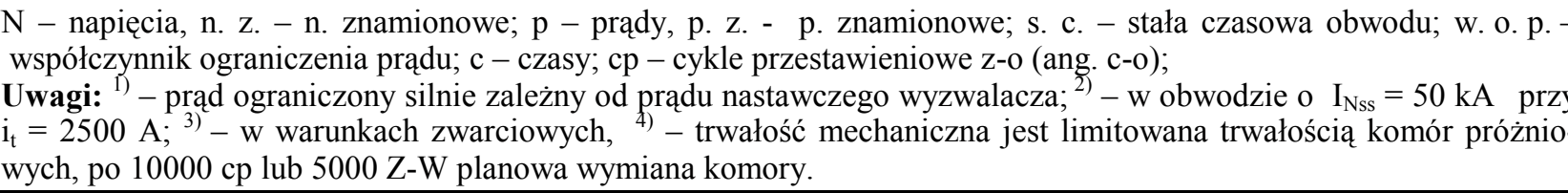 } \\
\hline
\end{tabular}

* - dane dla wyłaczników DCU, DCN i DCN-L produkowanych przez ZAE WOLTAN Sp. z o.o. na licencji Politechniki Łódzkiej. 
prądem wstecznym, wymaga specjalnych rozwiązań układu wyłączającego.

UW próżniowe (UWV) nie mają tego ograniczenia i są zdolne również do wyłączania tzw. prądów wstecznych, tj. prądów płynących $w$ kierunku przeciwnym do typowego dla systemie zasilania trakcji kolejowej. Przepływy prądu wstecznego w wylącznikach pojazdowych występują nie tylko w niektórych przypadkach zwarć w sieci trakcyjnej, ale w szczególności w przypadku hamowania odzyskowego i rekuperacji energii do sieci trakcyjnej. Przedstawiona niżej analiza pracy ultraszybkiego wyłącznika próżniowego $\mathrm{w}$ takich warunkach jest więc istotna zarówno z poznawczego, jak i praktycznego punktu widzenia. Ze względu na usytuowanie wylączników podstacyjnych $\mathrm{w}$ systemie zasilania trakcji kolejowej, wyłączanie prądu wstecznego przez taki wyłącznik nie ma $\mathrm{w}$ praktyce racjonalnego uzasadnienia $\mathrm{i}$ nie będzie dalej przedmiotem analizy, choć wyłączniki próżniowe DC z natury rzeczy są do tego zdolne.

\section{Metoda IPP jako zasada dzialania ukladu wy- lączającego próżniowego UWV.}

2.1. Wyłączanie metodą IPP silnych prądów stałych w obwodach o przewadze rezystancji.

Wyłączanie prądu stałego metodą IPP jest wieloetapowe. Przeanalizowane zostało na przykładzie układu wyłączającego UWV złożonego z głównego próżniowego zespołu wyłączającego ( $\mathrm{LG}$ ), zbocznikowanego gałęzią komutacyjną (GK), złożoną z generatora przeciwprądu $\mathrm{w}$ postaci naładowanego do napięcia $U_{k 0}$ kondensatora $C_{k}$ połączonego szeregowo $z$ dławikiem $\mathrm{L}_{\mathrm{k}}$ oraz próżniowym zespołem pomocniczym (ŁP) załączającym przeciwprąd. UWV jest także wyposażony w ogranicznik przepięć OP. Schemat UWV został pokazany na rys. 1 .

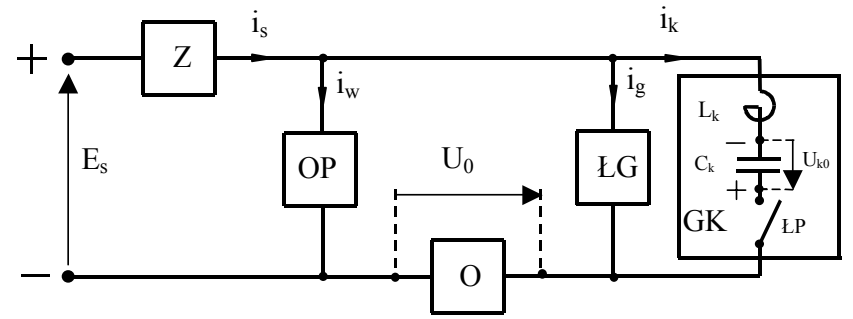

Rys. 1. Schemat blokowy UWV w obwodzie prądu stałego wyłączanym metodą IPP. Z - zastępcza impedancja falowa obwodu zwarciowego, $\mathrm{O}$ - odbiornik, $\mathrm{E}_{\mathrm{s}}$ - napięcie zasilające, $\mathrm{U}_{0}$ - napięcie na odbiorniku, $i_{s}$ - prąd sieci, $i_{g}$ - prąd łącznika głównego, $i_{k}$ - prąd komutacyjny, $i_{w}$ - prąd ogranicznika OP. Pozostałe oznaczenia w tekście.

Pod wpływem napięcia $\mathrm{U}_{\mathrm{k} 0}$ na kondensatorze $\mathrm{C}_{\mathrm{k}}$ następuje wymuszona komutacja prądu głównego $i_{g}$ do gałęzi komutacyjnej GK, a po wyłączeniu prądu w $\left\lfloor G\right.$ prąd $i_{k}$ przeładowuje kondensator $C_{k} i$ jest przejmowany przez $\mathrm{OP}$, będący warystorem tlenkowym o dużej energochłonności i nieliniowej charakterystyce napięciowo - prądowej gwarantującej ograniczenie przepięć na zadanym poziomie, rozładowanie energii magnetycznej obwodu oraz szybkie sprowadzenie prądu do zera.

Możliwe są dwa przypadki wyłączania:

- wyłączanie prądu roboczego odbiornika $\mathrm{O}$ gdy prąd $i_{s}=i_{g}$ zależy od parametrów odbiornika, a impedancja $\mathrm{Z}$ praktycznie nie wpływa na jego wartość,

- wyłączanie prądu zwarciowego gdy odbiornik jest zwarty, a o przebiegu prądu decyduje impedancja falowa $Z$.

Wyłączanie prądu $i_{\mathrm{s}}=\mathrm{i}_{\mathrm{g}} \mathrm{W}$ obu przypadkach odbywa $\mathrm{w}$ ten sam sposób. Po wystapieniu sygnału wyłączającego, wg zadanej sekwencji nastąi otwarcie ŁG i zamknięcie ŁP. W gałęzi komutacyjnej GK zaczyna płynąć prąd $i_{k}$. Ponieważ gałąź komutacyjna GK zawiera generator przeciwprąu o dużych możliwościach prądowych, proces komutacji odbywa się w bardzo krótkim czasie i można przyjąć, że w tym przedziale czasowym prąd $i_{\mathrm{s}}$ źródła jest praktycznie stały. A zatem słuszne jest równanie:

$$
\begin{gathered}
i_{s}=i_{g}+i_{k}=\text { const } \quad \text { lub } \\
i_{g}=i_{s}-i_{k} \quad \text { oraz } \quad \frac{d i_{g}}{d t}=-\frac{d i_{k}}{d t}
\end{gathered}
$$

z którego wynika, że szybkość malenia prądu $i_{\mathrm{g}}$ będzie taka sama jak szybkość wzrostu prądu $i_{k} \mathrm{w}$ gałęzi komutacyjnej GK. W chwili zrównania się prądu sieci $\mathrm{z}$ prądem gałęzi komutacyjnej $i_{\mathrm{s}}=\mathrm{i}_{\mathrm{k}}$ zostanie osiągnięta zerowa wartość prądu w łączniku głównym $i_{g}=$ 0 . W przypadku zastosowania wyłącznika $\mathrm{z}$ dwoma komorami próżniowymi i wyboru odpowiedniej sekwencji działania $Ł G$ i ŁP można uzyskać możliwość wylączania prądu przepływającego przez LG w dowolnym kierunku. UWV o takich właściwościach umożliwia więc budowę wyłącznika niespolaryzowanego. Współpracę łącznika głównego $\mathrm{LG} \mathrm{z}$ gałęzią komutacyjna GK omówiono na przykładzie wyłączania prądu roboczego $\mathrm{w}$ obwodzie o charakterze rezystancyjnym, a charakterystyczne przebiegi prądów i napięć pokazano na rys. 2 .

a)

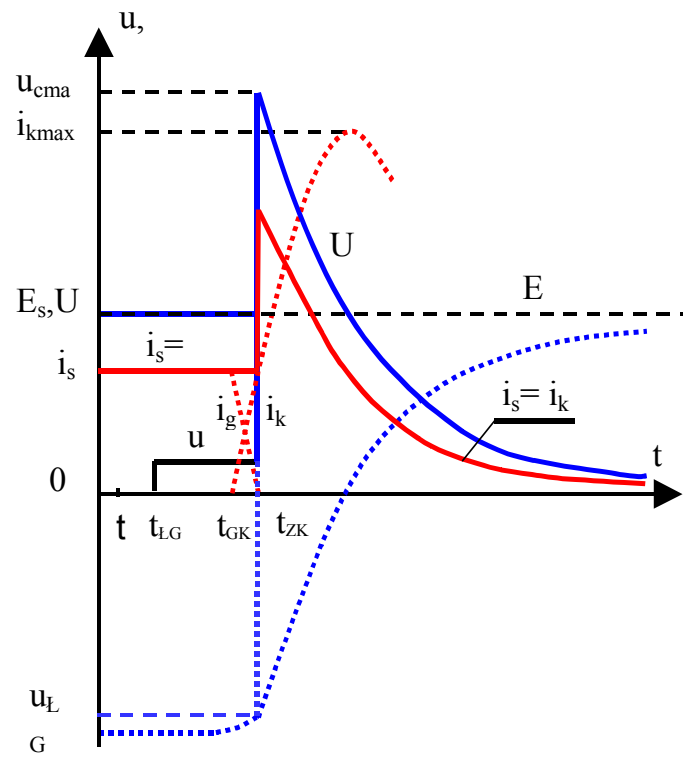


b)

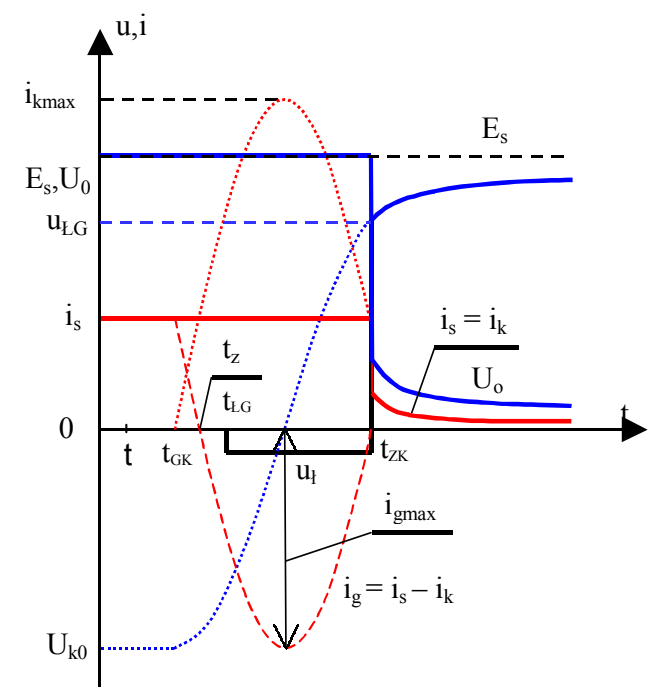

c)

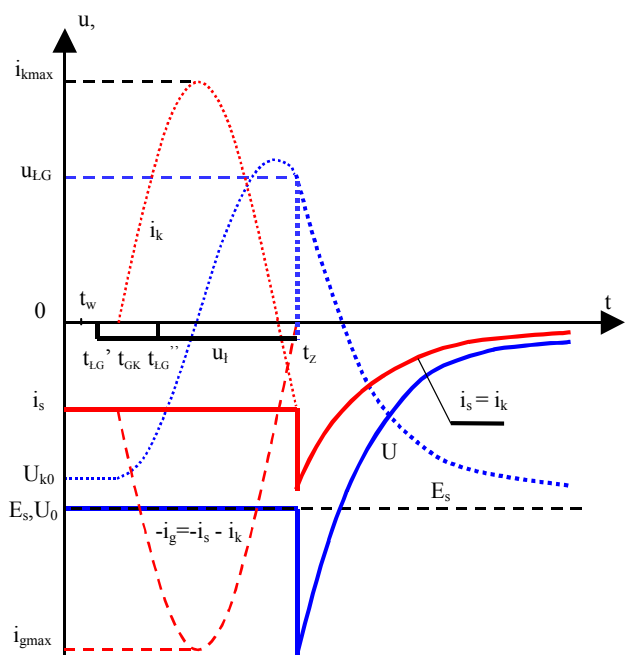

d)

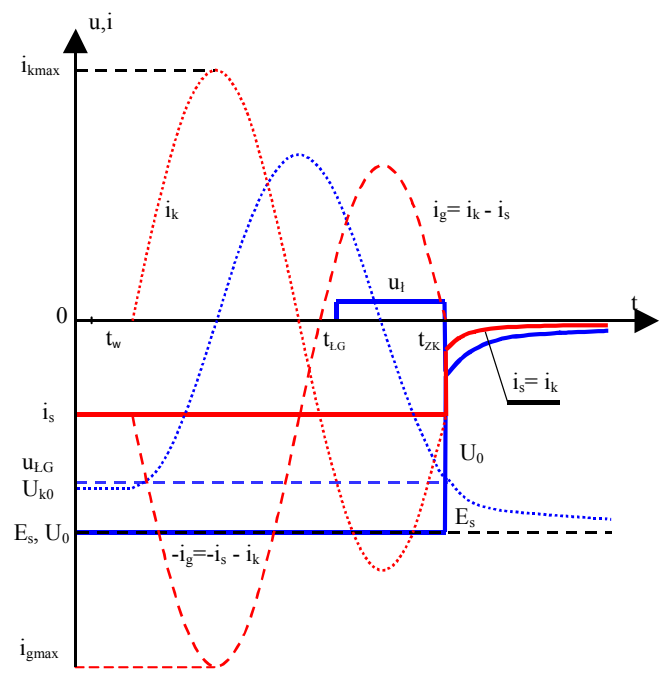

Rys. 2 a $\div$ d (c. d.) Współpraca łącznika głównego ŁG z gałęzią komutacyjną GK przy wyłączaniu metodą IPP prądu roboczego w obwodzie o charakterze rezystancyjnym: a) wyłączanie $\mathrm{w}$ pierwszym zerze prądu; b) wyłączanie w drugim zerze prądu; c) wyłączanie prądu wstecznego w pierwszym zerze prądu; d) wyłączanie prądu wstecznego $\mathrm{w}$ drugim zerze prądu. Chwile: $\mathrm{t}_{\mathrm{w}}-$ wystąpienia sygnału wyłączającego $t_{\mathrm{EG}}$, $t_{\mathrm{EG}}$ " - otwarcia łącznika głównego $Ł G, t_{\mathrm{GK}}$ - zamknięcia $Ł P \quad i$ zadziałania gałęzi komutacyjnej GK, $\mathrm{t}_{\mathrm{ZK}}$ - zakończenia komutacji wymuszonej; $\mathrm{U}_{\mathrm{k} 0}$ - napięcie początkowe na kondensatorze $\mathrm{C}_{\mathrm{k}}, \mathrm{u}_{\mathrm{cmax}}$ - maksymalne napięcie na kondensatorze $C_{k}, u_{1}$ - napięcie łuku w $L$ G. Pozostałe oznaczenia jak na rys. 1 .
2.1.1. Wyłączanie metodą IPP silnych prądów stałych zgodnych.

Gałąz komutacyjna GK wytwarza prąd o początkowym kierunku zawsze takim samym, niezależnym od kierunku prądu w wyłącznym obwodzie. Początkowo $\mathrm{w}$ obwodzie płynie prąd $i_{\mathrm{s}}=\mathrm{i}_{\mathrm{g}}$. Wystapienie $\mathrm{w}$ chwili $\mathrm{t}_{\mathrm{w}}$ sygnału wyłączającego skutkuje zadziałaniem gałęzi komutacyjnej GK i pojawieniem się prądu $\mathrm{i}_{\mathrm{k}} \mathrm{w}$ węzłach obwodu, do których gałąz ta jest dołaczona. W zależności od kierunku przepływu prądu obwodu $i_{s}$, w początkowej fazie wyłączania prądy $i_{k}$ oraz $\mathrm{i}_{\mathrm{g}}$ mogą mieć $\mathrm{w}$ węźle kierunki zgodne - jeżeli dopływają do węzła lub od niego odpływają albo przeciwne - gdy jeden z tych prądów dopływa do węzła a drugi od niego odpływa. Na rys. 2 a) pokazano przypadek wyłączania prądu metodą IPP z najczęściej stosowaną sekwencją współpracy gałęzi GK z łącznikiem $Ł G$, gdy najpierw otwiera się łącznik główny $Ł G$ $\mathrm{w}$ chwili $\mathrm{t}_{\mathrm{tG}}$, a następnie $\mathrm{w}$ chwili $\mathrm{t}_{\mathrm{GK}}$ wskutek załączenia $\left\lfloor P\right.$ pojawia się prąd $i_{k}$ o kierunku zgodnym $z$ prądem $i_{\mathrm{g}}$. A zatem wzrost prądu $i_{\mathrm{k}}$ powoduje malenie prądu $i_{g}$, w przedziale czasowym $t_{\mathrm{GK}} \div \mathrm{t}_{\mathrm{ZK}}$ następuje wymuszona komutacja prądu z łącznika $\mathrm{G}$ do GK. Wzrastający od zera prąd komutacyjny $i_{\mathrm{k}}$ osiagga $\mathrm{w}$ chwili $t_{Z K}$ wartość $i_{k}=i_{s}$. Wówczas prąd $i_{g}=0$, cały prąd sieci płynie przez GK i struktura obwodu ulega zmianie wskutek szeregowego dołączenia kondensatora $C_{k}$ do obwodu głównego. Jest to wyłączenie w pierwszym zerze prądu. Po skokowym wzroście początkowym prądu $i_{s}$, spowodowanym występującym na $C_{k}$ napięciem $u_{E G}$ sumującym się $z$ napięciem źródła $\mathrm{E}_{\mathrm{s}}$, prąd obwodu osiaga wartość zerową wskutek najczęściej aperiodycznego przeładowania kondensatora $\mathrm{C}_{\mathrm{k}}$ do napięcia sieci $\mathrm{E}_{\mathrm{s}}$. W takim przypadku maksymalne napięcie $\mathrm{u}_{\mathrm{cmax}}$ występuje na odbiorniku i nie pobudza do zadziałania ogranicznika przepięć $\mathrm{OP}$, gdyż jest na nim tylko napięcie $\mathrm{E}_{\mathrm{s}}$ przy którym prąd $\mathrm{i}_{\mathrm{w}}=0$, tj. OP nie bierze udziału w wyłączaniu prądu.

Druga sekwencja wyłączania prądu metoda IPP polega na tym, że najpierw działa gałąź komutacyjna GK wskutek zamknięcia ŁP w chwili $\mathrm{t}_{\mathrm{GK}}$, powodującego wzrost prąu $\mathrm{i}_{\mathrm{k}}$. Po przekroczeniu przez $i_{k}$ wartości prądu sieci $i_{k}>i_{s}$, w chwili $t_{\mathrm{EG}}$ otwiera się $\mathrm{\ell G}$, przez który płynie wówczas prąd $i_{g}=i_{s}-i_{k}$ osiagający wartość zerową $\mathrm{w}$ chwili $\mathrm{t}_{\mathrm{ZK}}$, na zboczu prądu $\mathrm{i}_{\mathrm{k}}$ malejącym od wartości maksymalnej $i_{\text {kmax }}$ do wartości $i_{k}=i_{s}$. Jest to wyłączenie w drugim zerze prądu. Jak w poprzednim przypadku struktura obwodu ulega zmianie wskutek szeregowego dołączenia kondensatora $C_{k}$ do obwodu głównego. Po skokowym zmaleniu początkowym prądu $i_{s}$ spowodoźródła $\mathrm{E}_{\mathrm{s}}$, prąd obwodu osiąga wartość zerową wskutek najczęściej aperiodycznego przeładowania kondensatora $\mathrm{C}_{\mathrm{k}}$ do napięcia sieci $\mathrm{E}_{\mathrm{s}}$.

$\mathrm{W}$ obu powyższych przypadkach wyłączania istnieją określone różnice $\mathrm{w}$ warunkach pracy wybranych podzespołów układu wyłączającego. Przy wyłączaniu w pierwszym zerze prądu warunki pracy 
łącznika głównego ŁG są łatwe, gdyż w czasie palenia się łuku przepływa przezeń prąd nie większy od prądu sieci $i_{g} \leq i_{s}$, natomiast warunki napięciowe $i$ energetyczne dla odbiornika $\mathrm{O}$ oraz pozostałych elementów są relatywnie trudne. Przy wyłączaniu w drugim zerze prądu warunki pracy łącznika głównego $\mathrm{LG}$ są cięższe. W każdym przypadku wyłączania przepływa przezeń duży prąd $i_{g}=i_{s}-i_{k}, w$ chwili $t_{z z}$ zmieniający kierunek $\mathrm{i}$ osiagający dużą wartość maksymalną $i_{\text {gmax }}=i_{s}-i_{\text {kmax }}$, tym większą im mniejszy jest wyłączany prąd (rys. 2 b). Jednak po komutacji $w$ chwili $t_{z z}$ warunki energetyczne elementów układu wyłączającego oraz odbiornika są łatwiejsze z przyczyn opisanych wyżej.

\subsubsection{Wyłączanie metodą IPP silnych prądów stałych wsteczych.}

Wyłączanie prądów wstecznych pokazano na rys. 2 c) oraz 2 d). Wyłączanie prądu wstecznego w pierwszym zerze prądu (rys. 2 c) nastapi w wytwarzanej przez GK drugiej, ujemnej półfali prądu $i_{k}$, na jej ujemnym zboczu malejącym od wartości zerowej do wartości - $\mathrm{i}_{\mathrm{kmax}}$. Zjawiska łączeniowe oraz narażenia elementów układu wyłączającego i obwodu są dokładnie takie same, jak w przypadku pokazanym na rys. 2 a), ponieważ $w$ obu przypadkach prąd $i_{\mathrm{g}}$ płynący przez $Ł G$ nie zmienia kierunku przepływu. Prąd ten, równy $-i_{\mathrm{g}}=-\mathrm{i}_{\mathrm{s}}-\mathrm{i}_{\mathrm{k}}$, w chwili $\mathrm{t}_{\mathrm{ZK}}$ osiaga wartość zerowa. Zadziałanie $Ł G$ praktycznie nie jest czasowo powiązane $\mathrm{z}$ zadziałaniem $Ł P$ i załączeniem GK. Może ono nastąpić zarówno $w$ chwili t ${ }_{\mathrm{EG}}$, jak również $w$ chwili $t_{t G}$ ", o ile napęd łącznika $\measuredangle G$ jest dostatecznie szybki. Podobne analogie występują pomiędzy stylizowanymi przebiegami dotyczącymi wyłączania w drugim zerze prądu zgodnego (rys. 2 b) oraz wstecznego (rys. 2 d). Różnica zasadnicza, nie wpływająca na zjawiska łączeniowe, dotyczy umiejscowienia chwili $t_{\mathrm{EG}}$, która musi być związana $\mathrm{z}$ ujemną półfalą prądu $i_{k}$ wytworzoną przez GK. Należy dodać, że tylko $\mathrm{w}$ pierwszym przypadku wyłączania prądu $\mathrm{i}_{\mathrm{g}}$ o kierunku zgodnym z prądem $i_{k}$, przez $Ł G$ nie przepływa maksymalna wartość prądu komutacyjnego $i_{\text {kmax }}$ wytwarzanego przez GK. W trzech pozostałych przypadkach wyłączania prądu metodą IPP, przed chwilą zera prąu $\dot{i}_{\mathrm{g}}$ przez $Ł G$ przepływają jedna lub dwie pófale prądu $i_{\text {kmax }}$.

2.2. Wyłączanie metodą IPP silnych prądów stałych w obwodach o przewadze indukcyjności.

Wyłączanie prądu metodą IPP obwodów zawierających indukcyjność opisano na przykładzie analizy wyłączania zwarcia, jako przypadku najtrudniejszego, a zarazem najbardziej typowego.

Ogólny schemat zwartego obwodu trakcyjnego jest odwzorowany schematem zastępczym pokazanym rys. 3. Generatorem przeciwprądu GP w gałęzi komutacyjnej, załączanym przez $Ł P$, jest naładowany do napięcia $\mathrm{U}_{\mathrm{ck} 0}$ kondensator $\mathrm{C}_{\mathrm{k}}$ połączony szeregowo $\mathrm{Z}$ dławikiem komutacyjnym o niewielkiej indukcyjności
$\mathrm{L}_{\mathrm{k}}$. Obwód główny jest odwzorowany skupioną indukcyjnością $L_{s}$ oraz rezystancją $R_{s}$. Ogranicznik przepięć OP zastapiono warystorem $\mathrm{W}$ o charakterystyce napięciowo - prądowej utrzymującej w szerokich granicach prawie niezmienne napięcie, niezależne od przepływającego przezeń prądu.

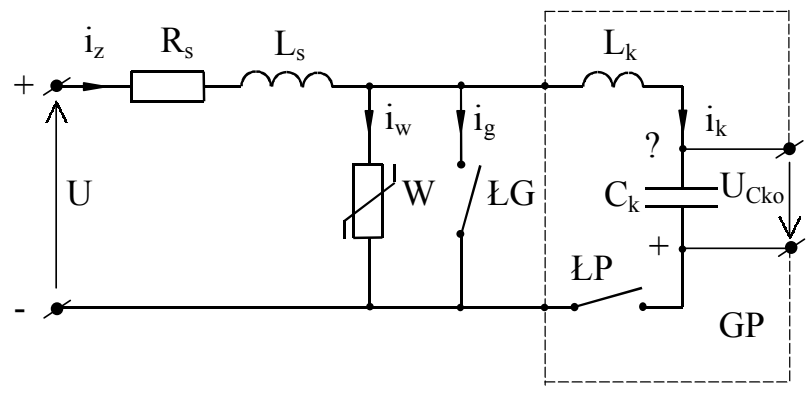

Rys. 3. Schemat ideowo - blokowy zwarciowego obwodu prądu stałego wyłączanego metodą IPP Oznaczenia jak na rys. 1 oraz w tekście.

\subsubsection{Wyłączanie metodą IPP silnych prądów stałych zgodnych.}

W stanie początkowym obydwa łaczniki ŁG i ŁP sa otwarte, a kondensator $C_{k}$ jest naładowany do napięcia początkowego $\mathrm{U}_{\mathrm{Cko}}$. Zamknięcie łącznika $\mathrm{LG} \mathrm{w}$ dowolnej chwili $\mathrm{t}=0$ jest równoznaczne $\mathrm{z}$ załączeniem obwodu zwarciowego o parametrach $\mathrm{R}_{\mathrm{s}}, \mathrm{L}_{\mathrm{s}}$ w którym pod wpływem napięcia zasilającego $U$ rozpoczyna wykładniczo wzrastać prąd zwarciowy $i_{z}$ o spodziewanej wartości ustalonej $I_{z u}=U / R_{s}$ i początkowej stromości $\mathrm{s}=\mathrm{di}_{\mathrm{z}} / \mathrm{dt}=\mathrm{U} / \mathrm{L}_{\mathrm{s}}$. Po osiągnięciu przez prąd $i_{z}$ zadanej wartości $I_{d}$ następuje uruchomienie procesu wyłączania zwarcia metodą IPP. Przebiegi prądów i napięć podczas wyłączania zwarcia pokazano na rys. 4 dla przypadków wyłączania w pierwszym lub drugim zerze prądu.

a)

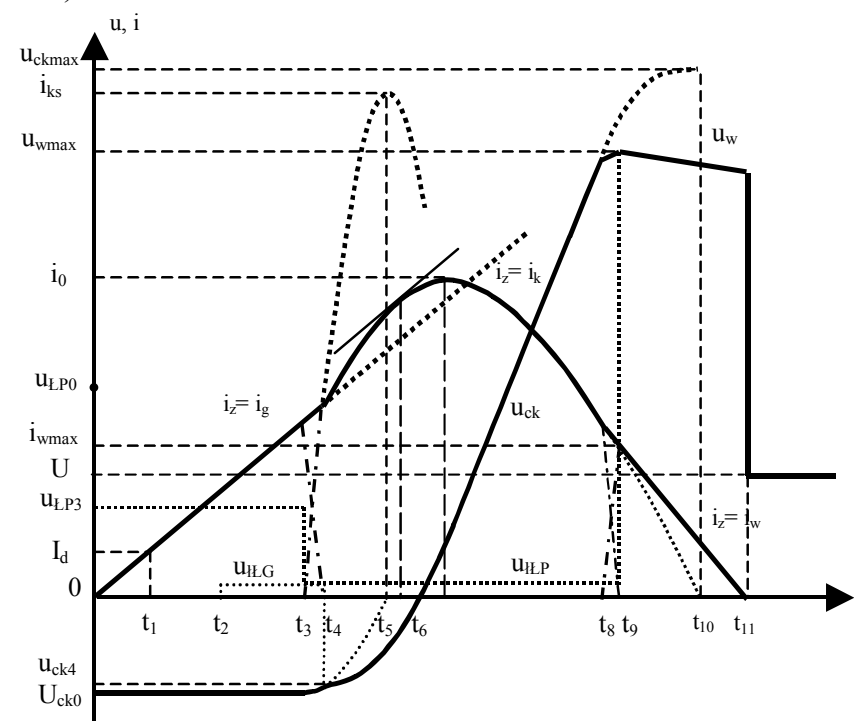


b)

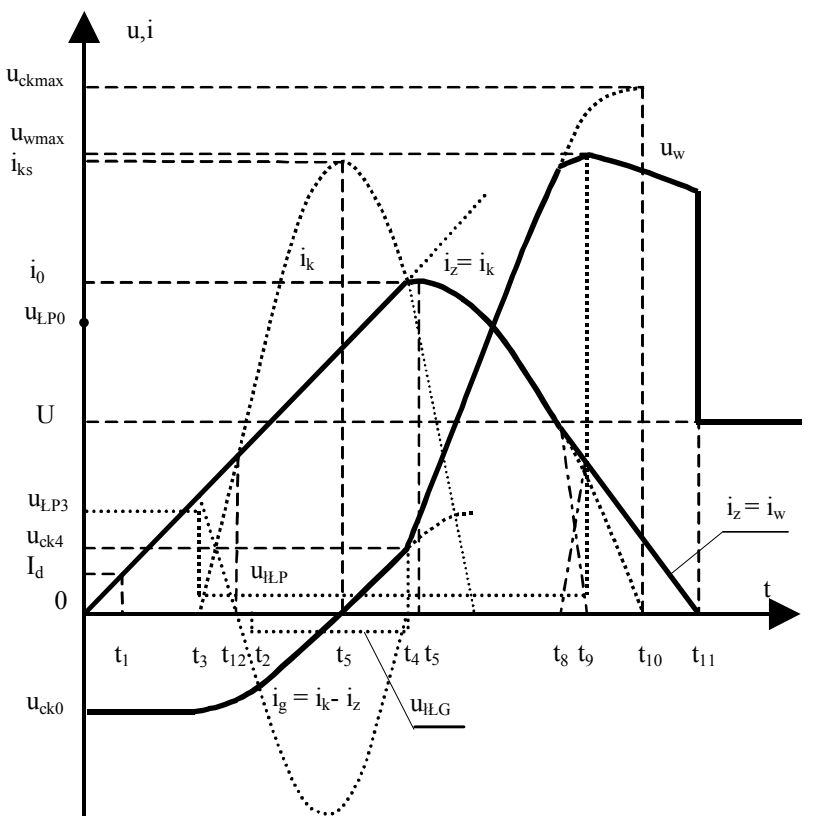

Rys. 4. Stylizowane przebiegi napięć i prądów podczas wyłączania prądu stałego metodą IPP, w obwodzie według rys. 3: a) w pierwszym zerze prądu, b) w drugim zerze prądu. Oznaczenia niżej oraz w tekście.

Oznaczenia do rys. 4 a, $\boldsymbol{b} \rightarrow$ napięcia: $U$-napięcie zasilajace, $U_{E P 0}-$ na $Ł P$ po załaczeniu zasilania, $U_{E P 3}-$ na $L P$ po załaczeniu wytacznika, $U_{c k 4}-n a$ kondensatorze $C_{k} w$ chwili dojścia do zera pradu $w \in G, \quad U_{\text {ckmax }}$ - maksymalne na kondensatorze $C_{k} w$ przypadku braku warystora $W, u_{\text {wmax }}$ - maksymalne na warystorze $W$, $u_{t E G}-$ napięcie tuku na $\measuredangle G$, $u_{t Ł P}$ - napięcie tuku na $E P$; prady: $I_{d}-$ nastawczy (zadziałania), $i_{k s}-$ wartość szczytowa $i_{k}, i_{\text {wmax }}-$ maksymalny warystora, $i_{o}$ - ograniczony obwodu; chwile: $t_{0}$ - załaczenia obwodu zwartego, $t_{1}$ - zadziałania wyzwalacza wyłacznika, $t_{2}-$ otwarcia $\measuredangle G, t_{3}$-zamknięcia $\measuredangle P, t_{4}-$ wytqczenia pradu $w \measuredangle G, t_{5}$ - wystapienia pradu $i_{k s}, t_{6}-$ wystapienia stromości pradu $i_{z}$ równej jego stromości poczatkowej, $t_{7}-$ wystapienia pradu $i_{o}, t_{8}-$ zadziatania warystora $W, t_{9}$ - calkowitego przejęcia pradu przez warystor $W, t_{10}$-wytaczenia obwodu o matej energii bez udziatu warystora $W, t_{11}$-zaniku pradu $w$ warystorze $W$ oraz zakończenia wyłaczania obwodu, $t_{12}$ - zmiany kierunku przeptywu pradu $w$ łqczniku głównym ŁG. Pozostałe oznaczenia jak na rys. 3 oraz $w$ tekście.

Przy wyłączaniu zwarcia w pierwszym zerze prądu, niepokazany na rys. 3 naped otwiera łacznik ŁG i z założonym opóźnieniem zamyka łącznik ŁP na dowolnie krótki czas. Pojawienie się w obwodzie napięcia na kondensatorze $C_{k}$ rozpoczyna proces wymuszonego przejmowania prądu $i_{\mathrm{g}} \mathrm{z}$ łącznika $\mathrm{\iota G}, \mathrm{w}$ którym pali się łuk elektryczny, przez gałąź komutacyjną zawierającą $\mathrm{L}_{k}, \mathrm{C}_{\mathrm{k}} \mathrm{i}$ ŁP. Wzrastający ze stromością $\mathrm{s}_{\mathrm{k}}=\mathrm{U}_{\mathrm{Ck} 0} / \mathrm{L}_{\mathrm{k}}$ prąd $\mathrm{i}_{\mathrm{k}}$ zamyka się $\mathrm{w}$ obwodzie $\mathrm{C}_{\mathrm{k}}, \mathrm{LP}, \mathrm{U}^{\mathrm{U}}{ }^{+} \mathrm{U}, \mathrm{R}_{\mathrm{s}}, \mathrm{L}_{\mathrm{s}}, \mathrm{L}_{\mathrm{k}}, \mathrm{C}_{\mathrm{k}}$, powodując szybkie malenie do zera prąadu $\mathrm{i}_{\mathrm{g}}$, gdyż $\mathrm{di}_{\mathrm{g}} / \mathrm{dt}=-\mathrm{di}_{\mathrm{k}} / \mathrm{dt}$. W chwili $\mathrm{t}_{4}$ osiaggnięcia przez prąd $\mathrm{i}_{\mathrm{g}}$ wartości zerowej, następuje zmiana struktury obwodu, cały prąd obwodu płynie przez gałąz komutacyjną. Na stykach łącznika głównego $Ł G$ pojawia się skokowo napięcie $U_{\mathrm{Ck} 4}$ częścio- wo rozładowanego kondensatora $\mathrm{C}_{\mathrm{k}}$, mniejsze od napięcia $U_{\mathrm{Ck} 0}$. Przy wyłączaniu małych prądów napięcie $\mathrm{U}_{\mathrm{Ck} 4}$ jest bliskie napięciu $\mathrm{U}_{\mathrm{Ck} 0}$, zaś w miarę wzrostu wyłączanego prądu do wartości granicznej napięcie $\mathrm{U}_{\mathrm{Ck} 4}$ maleje do wartości bliskich zeru. Parametry gałęzi komutacyjnej $\mathrm{U}_{\mathrm{Ck} 0}, \mathrm{C}_{\mathrm{k}}, \mathrm{L}_{\mathrm{k}}$ muszą być tak dobrane, aby mogła ona przejąć prąd graniczny wyłącznika przed zmianą biegunowości napięcia $U_{\text {Cko }}$.

W dalszym ciagu procesu wyłączania moga wystapić dwa przypadki, w zależności od energii magnetycznej zgromadzonej w obwodzie. Przy dużych energiach zgromadzonych $\mathrm{w}$ indukcyjności $\mathrm{L}_{\mathrm{s}}$, kondensator $\mathrm{C}_{\mathrm{k}}$ przejmuje tylko część tej energii, gdyż pojawiające się na nim napięcie zostanie ograniczone do poziomu ochrony przeciwprzepięciowej, narzuconego przez silnie nieliniową charakterystykę warystora W. Następuje wówczas szybka komutacja prądu do warystora i całkowity prąd płynie przez obwód ${ }^{+} U, R_{s}$, $\mathrm{L}_{\mathrm{s}}, \mathrm{W}, \mathrm{U}$. Utrzymujące się na warystorze $\mathrm{W}$ dość wysokie napięcie niewiele zmienia się $\mathrm{w}$ szerokich granicach zmian prądu, powodując szybkie malenie do zera prądu $i_{z}$, po czym napięcie na warystorze $W$ wraca do poziomu napięcia sieci U. Proces wyłączania obwodu kończy się więc po zaistnieniu czterech etapów wyłączania:

- etapu komutacji wymuszonej napięciem $\mathrm{U}_{\mathrm{Ck} 0}$ w przedziale czasowym $t_{3} \div t_{4}$,

- etapu swobodnego przeładowywania kondensatora $\mathrm{C}_{\mathrm{k}} \mathrm{W}$ przedziale czasowym $\mathrm{t}_{4} \div \mathrm{t}_{7}$,

- etapu naturalnej komutacji prądu $\mathrm{z}_{\mathrm{k}}$ do warystora $\mathrm{W}$ w przedziale czasowym $\mathrm{t}_{7} \div \mathrm{t}_{8}$,

- etapu sprowadzania do zera prądu $i_{z}$ przez warystor $\mathrm{W} w$ przedziale czasowym $\mathrm{t}_{8} \div \mathrm{t}_{10}$.

Przy wyłączaniu zwarcia $\mathbf{w}$ drugim zerze prądu sekwencja działania $Ł G$ oraz $Ł P$ jest odwrotna do wyżej opisanej i analogiczna do pokazanej na rys. $2 \mathrm{~b}$, tj. otwarcie $\measuredangle G$ w chwili $t_{2}$ następuje po załączeniu $Ł P$ $\mathrm{w}$ chwili $\mathrm{t}_{3}$. Pokazane to zostało na rys. $4 \mathrm{~b}$. Opis poszczególnych etapów wyłączania zwarcia oraz charakterystycznych przedziałów czasowych jest zbliżony do przypadku wyłączania zwarcia w pierwszym zerze prądu. Istotne różnice polegają na innym sposobie przeładowywania się kondensatora $\mathrm{C}_{\mathrm{k}}$ oraz na zmianie biegunowości napięcia łuku w ŁG.

Przypadek ten jest trudniejszy energetycznie dla łącznika $\mathrm{LG}$, gdyż przepływa przezeń maksymalny prąd obwodu komutacyjnego. Dzięki zmianie biegunowości napięcia $U_{\mathrm{Ck}}$ na kondensatorze $\mathrm{C}_{\mathrm{k}}$ występują jednak łagodniejsze warunki energetyczne dla warystora W. Jak wynika z przebiegów pokazanych na rys. 4, przy wyłączaniu w pierwszym zerze prądu napięcie $\mathrm{U}_{\mathrm{Ck} 4}$ dodaje się do napięcia zasilającego, powodując późniejsze dojście do zera prądu głównego, niż to ma miejsce przy wyłączaniu w drugim zerze prądu, gdy napięcie $U_{\mathrm{Ck} 4}$ odejmuje się od napięcia zasilającego. Zmiana biegunowości napięcia łuku dyfuzyjnego $\mathrm{w}$ ŁG jest korzystna z punktu widzenia szybkości odzy- 
skiwania wytrzymałości powrotnej próżni [5].

\subsubsection{Wyłączanie metodą IPP silnych prądów stałych wstecznych.}

Prądy wsteczne w rzeczywistych sieciach trakcji kolejowej występują w kilku szczególnych przypadkach, przy czym ich wyłączanie nie zawsze jest wskazane lub potrzebne. Do takich typowych przypadków można zaliczyć $\mathrm{m}$. in.:

1. przepływ prądu wstecznego przez wyłącznik pojazdowy podczas hamowania odzyskowego pojazdu połączonego $\mathrm{z}$ oddawaniem energii do sieci,

2. przepływ prądu wstecznego przez wyłącznik w kabinie sekcyjnej w szczególnych przypadkach zasilania odcinka sieci trakcyjnej i położenia pojazdu na odcinku,

3. przepływ prądu wstecznego przez wyłącznik pojazdowy, w przypadku zwarcia w sieci trakcyjnej, wskutek rozładowywania się kondensatora filtru w przypadku pojazdu z napedem prądu przemiennego zasilanym za pomocą przekształtników, etc.

Jakkolwiek wyłączenie prądu wstecznego jest wskazane tylko w ostatnim przypadku, kierując się zasadą przezorności należy przyjąć, że zadziałanie ultraszybkiego wyłącznika próżniowego wykorzystującego metodę IPP może się $\mathrm{z}$ różnych przyczyn zdarzyć w dowolnej chwili i w dowolnych warunkach, a więc prądy wsteczne zawsze muszą być wyłączane poprawnie.

Analizę wyłączania prądów wstecznych przy wykorzystaniu metody IPP przedstawiono dla wyżej opisanych przypadków 2 i 3 (w przypadku 1 i 2 wyłączanie prądu wstecznego ma podobny charakter). Schematy zastępcze dla tych przypadków pokazane zostały na rys. 5 .

W przypadku pokazanym na rys. 5. a) odcinek trakcyjny zazwyczaj zasilany dwustronnie ma wyłączoną podstację P1, w pobliżu której jest pojazd PE pobierający prąd płynący przez kabinę sekcyjną $\mathrm{z}$ podstacji P2. Przy konfiguracji wyłączników pokazanej na rysunku przez zamknięty wyłącznik 5 płynie prąd wsteczny $i_{w}$, który dla wyłączników 3 oraz 7 jest prądem zgodnym.

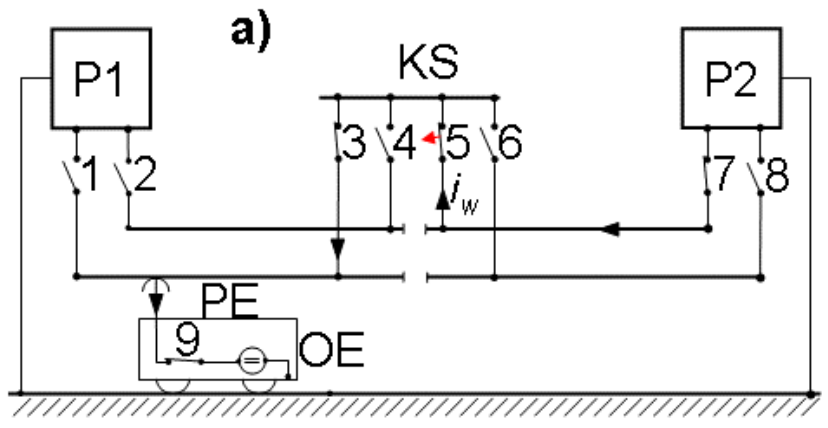

W przypadku uruchomienia procesu wyłączania tego prądu przez wyłącznik 5 będzie wyłączany relatywnie mały prąd roboczy pobierany przez pojazd. Stylizowane przebiegi łączeniowe prądów i napięć dla takiego przypadku zostały pokazane na rys. 6. a).

Jeżeli przy takiej konfiguracji obwodu w części odcinka sieci między podstacją P1 a kabiną KS pojawi sie zwarcie, to popłynie prąd zwarciowy, wsteczny tylko w wyłączniku 5, o relatywnie małej stromości zmian i spodziewanej wartości ustalonej wskutek ograniczania tych wielkości przez bierne parametry sieci trakcyjnej. W zależności od nastaw prądowych (tj. prą̧ów zadziałania wyzwalaczy), do działania mogą być pobudzone wyłączniki 3, 5 i 7, a przy zwarciu $\mathrm{w}$ pojeździe także wyłącznik 9 . W tym ostatnim przypadku zawsze on selektywnie wyłączy zwarcie jako najszybszy i mający najmniejszą nastawę prądową. Przy zbliżonych nastawach prądowych wszystkie wyłączniki moga być pobudzone do działania, ale tylko najszybszy wyłączy zwarcie, a pozostałe będa pracowały bezłukowo. Wyłącznik 5 wyłączy więc prąd wsteczny tylko wówczas, gdy jego nastawa prądowa będzie mniejsza od nastaw wyłączników 3 i 7 . Przebiegi łączeniowe prądów i napięć będą wówczas jakościowo podobne do przebiegów pokazanych na oscylogramie wg rys. 6. b), charakteryzujących przedstawiony na schemacie wg rys. 5. b) przypadek wyłączania prądu wstecznego podczas zwarciowego rozładowywania się kondensatora $\mathrm{C}_{\mathrm{f}}$ filtru napędu $\mathrm{NP}_{\mathrm{AC}}$ przy zwarciu w sieci trakcyjnej poza analizowanym pojazdem.

Rys. 5. Uproszczone schematy zastępcze obwodów w przypadkach występowania przepływu prądów wstecznych: a) przez wyłącznik w kabinie sekcyjnej, b) przez wyłącznik pojazdu ze sterowanym przekształtnikowo napędem AC w przypadku zwarcia w sieci trakcyjnej. PE - pojazd $\mathrm{z}$ odbiornikami OE; EZT - pojazd z napędem $\mathrm{NP}_{\mathrm{AC}}$ j. w.; $1 \div 9$, W - wyłączniki; $\mathrm{P} 1, \mathrm{P} 2$ - podstacje; $\mathrm{KS}$ - kabina sekcyjna; filtr: $\mathrm{L}_{\mathrm{f}}-$ dławik, $\mathrm{C}_{\mathrm{f}}$ - kondensator; $\mathrm{i}_{\mathrm{w}}$ - prądy wsteczne.

\section{b)}

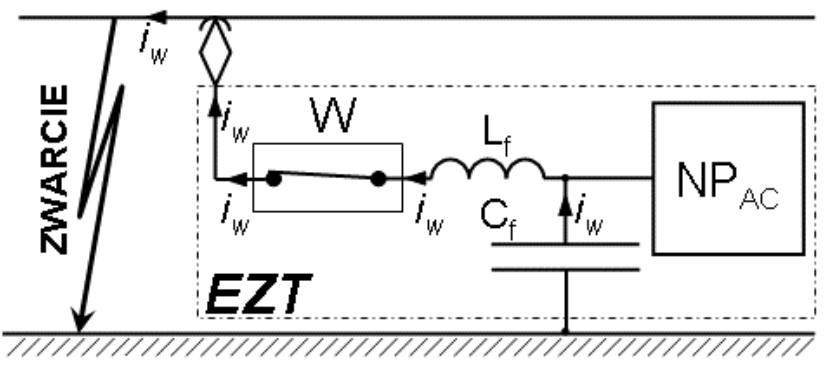


a)

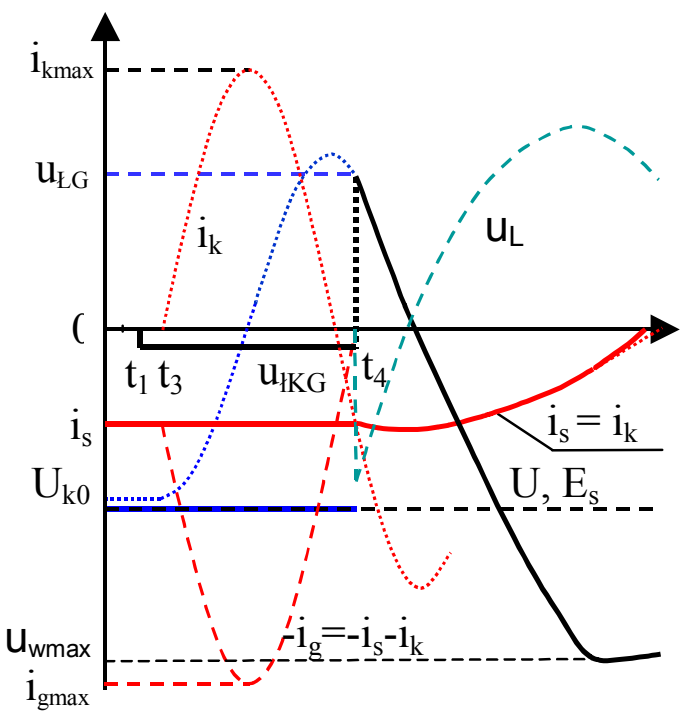

b)

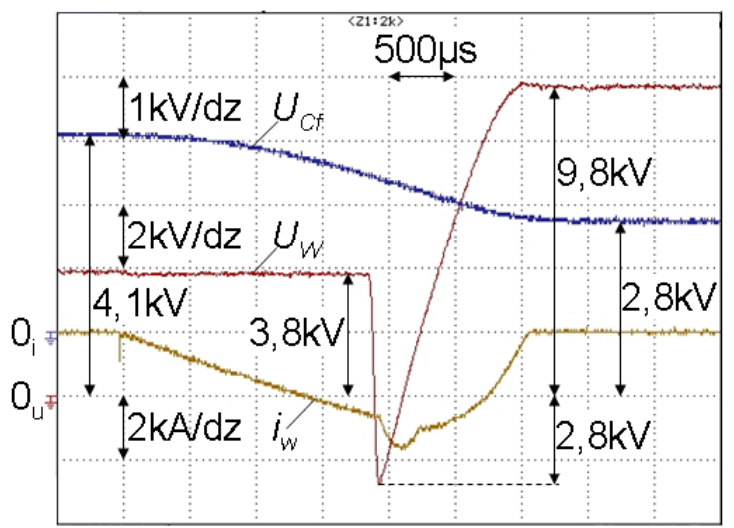

Rys. 6. Przebiegi łączeniowe prądów i napięć przy wyłączaniu metodą IPP prądów wstecznych w obwodzie o przewadze indukcyjności: a) stylizowane przebiegi łączeniowe prądów i napięć dla przypadku wyłączania prądu roboczego w układzie wg rys. 5. a); b) oscylogram przebiegów łączeniowych prądów i napięć przy wyłączaniu prądu wstecznego podczas rozładowywania się kondensatora $\mathrm{C}_{\mathrm{f}}$ filtru napędu $\mathrm{NP}_{\mathrm{AC}}$ przy zwarciu w sieci trakcyjnej, $\mathrm{w}$ układzie wg rys. 5. b); wyłączanie w pierwszym zerze prądu; konfiguracja wyłącznika jak na rys. 3 . $U_{\mathrm{W}}$ - napięcie na wyłączni$\mathrm{ku} \mathrm{W}, \mathrm{U}_{\mathrm{Cf}}$ - napięcie na kondensatorze $\mathrm{C}_{\mathrm{f}}, \mathrm{U}_{\mathrm{L}}$ - napięcie na dławiku $\mathrm{L}_{\mathrm{f}} \mathrm{t}_{\mathrm{z}}$-chwila wystapienia zwarcia, $0_{\mathrm{i}}, 0_{\mathrm{u}}$ - zera prądów lub napięć (wg. rys. 5.b). Pozostałe oznaczenia jak na rys. 3, 4, 5 oraz w tekście.

Po uruchomieniu wyłącznika wykorzystującego metodę IPP, $\mathrm{w}$ chwili $\mathrm{t}_{1}$ następuje otwarcie komory $\mathrm{KG}$ i zapłon łuku o napięciu $\mathrm{u}_{\mathrm{tKG}}$. W chwili $\mathrm{t}_{3}$ następuje zamknięcie komory KP i załączenie oscylacyjnego prądu $i_{k}$ sumującego się $z$ prądem $i_{s} w$ komorze $K G$, przez którą przepływa duży prąd szczytowy $\mathrm{i}_{\text {gmax }}$. Narażenie energetyczne komory KG jest wówczas duże. Kondensator komutacyjny podczas przepływu półfali prądu $i_{k}$ przeładowuje się. Po sprowadzeniu w chwili $t_{4}$ prądu $i_{s}$ do zera następuje zmiana konfiguracji obwodu, w którym pojawia się szeregowo dołączony kondensator $C_{k}$ o napięciu $u_{\mathrm{EG}}$. Przy znacznej indukcyjności obwodu i zawartej w niej energii magnetycznej, kondensator komutacyjny jest dalej prze- ładowywany, aż do osiagnnięcia wartości $\mathrm{u}_{\mathrm{wmax}}$ napięcia zadziałania ogranicznika przepięć, w którym następuje rozładowanie pozostałej energii magnetycznej. Następnie (poza zakresem rys. 6. a) napięcie na kondensatorze komutacyjnym powraca do wartości $\mathrm{U}_{\mathrm{k} 0}$.

W przypadku pokazanym na rys. 5. b) oraz 6 . b), po wystapieniu zwarcia $\mathrm{w}$ chwili $\mathrm{t}_{\mathrm{z}}$ sekwencja działania wyłącznika jest podobna. Ponieważ wartości $\mathrm{L}_{\mathrm{f}}$ oraz $\mathrm{C}_{\mathrm{f}}$ są duże, szybkość wzrostu prądu wstecznego nie jest zbyt duża. Po wyłączeniu $\mathrm{w}$ chwili $\mathrm{t}_{4}$ prądu wstecznego w komorze KG oraz zmianie konfiguracji obwodu, napięcie na wyłączniku wzrasta aż do osiągnięcia wartości napięcia zadziałania ogranicznika przepięć (wskutek doładowywania kondensatora komutacyjnego energią elementów $\mathrm{L}_{\mathrm{f}}$ i $\mathrm{C}_{\mathrm{f}}$ filtru) i ostatecznego wyłączenia prądu wstecznego $\mathrm{w}$ chwili $\mathrm{t}_{10}$.

\section{Wnioski.}

Metoda IPP jako zasada działania ultraszybkich wyłączników próżniowych prądu stałego nie ma teoretycznych ograniczeń stosowalności w dowolnych warunkach lączeniowych spotykanych w sieciach trakcji kolejowej zasilanej napięciami stałymi o wartościach do $3 \mathrm{kV}$.

\section{Literatura.}

[1]. Bartosik M.: Direct current switching off in vacuum. Proceedings of the VIth International Conference on Switching Arc Phenomena. SAP-89, Postconf. materials, Lódź, Poland, 1989.

[2]. PN-69/E-06120 - Pojazdy trakcyjne. Aparaty elektryczne pradu statego. Ogólne wymagania $i$ badania.

[3]. PN-74/E-06121-Aparatura trakcyjna. Wytaczniki szybkie pradu statego. Wspólne wymagania $i$ badania.

[4]. PN-EN 50123:-Zastosowania kolejowe. Urzadzenia stacjonarne. 50123-1 - Aparatura łaczeniowa pradu stałego. Wymagania ogólne. 50123-2 - Aparatura taczeniowa pradu statego. Wytaczniki pradu stałego.

[5]. Zatucki Z.: Wytrzymatość i izolacja elektryczna próżni. Rozprawa habilitacyjna. Zeszyty Naukowe Politechniki Poznańskiej, Rozprawy nr 180, Poznań, 1986. 